\title{
Study of cooperative education pattern
}

\author{
Zhang Li-ping, Yu Qiu \\ Shanghai University of Engineering Science, Shanghai 201620, China
}

Email address:

yuqiu@vip.citiz.net(Yu Qiu)

\section{To cite this article:}

Zhang Li-ping, Yu Qiu. Study of Cooperative Education Pattern. Science Journal of Education. Vol. 1, No. 5, 2013, pp. 60-63. doi: $10.11648 /$ j.sjedu.20130105.12

\begin{abstract}
In this paper, we explore the pattern of cooperative education which is based on automobile engineering. This means the university and enterprises will pay their common efforts to cultivate talent students. And how to do it well would be our real purpose, practice and research we should do now and then. In the research we find out that cooperative education is the important means of excellent engineer's training which is compatible with economic development and coordinated with education reform. We also establish a base for both university and enterprises to fulfill this cooperative education. After several years practice and research we get some ideas and results which can lead us to go on doing it well. Finally, we point out something we need to improve later, and the difficult we are now face to realize this improvement. And also a conclusion is mentioned.
\end{abstract}

Keywords: Cooperative Education, School-Enterprise Cooperation, Excellence Engineer's Education

\section{Introduction}

The personnel training cannot isolate from the social environment. And also it is necessary for a person, especially the student, to be trained in a real working environment that he or she will develop and acquire the knowledge, engineering practicing experience, innovation ideas and even personality character with whom a high quality talent must possess. In this new and ever-changing world, institutions of higher learning must catch up with the need of society and at the same time come up to the rule of education and teaching, so that we can carry out a mode which the education system, ideas, mechanism and effects would be fully accord and satisfaction with each other. In this way, the education of a university can serve our society. Especially it can cultivate more talents for local economic construction. These are important issue for us to explore and pay a deep attention to do research.

Based on the need of development of university itself, some main steps are being conducted such as the cooperation of the school and enterprise; combing leaning, research and production with each other, connection the tracks between study and markets. Under the principles of equal volunteer, mutual benefits and complement each other's advantages, the university and enterprise have established a long term relationship on every side. They will both have efforts to cultivate person with high quality of ideas for innovation, the need of economy development.

\section{The Research We Are Undertaking}

(1). Doing the research to meet with the need of the industrial structural adjustment of shanghai, the means of combing them with the localized education of our school. So the targets of our school education can be realized to cultivate high quality talents with engineering practicing experience, and also to establish an advanced university with its own characteristics.

Recently, the electrical and electronic college of our university has paid close attention to the need of the industrial structural adjustment and economic development of shanghai, we have changed or optimized the professional setting and method of personal training. For example, the major of automobile electronics is now the sun-rise industry of shanghai, so we have established close tie with some automobile factories for both study and practicing. Meanwhile this doing not only promotes professional setting but also reflects the characteristics ourselves.

(2). Doing research for following out the spirits of long term development and innovation of the state education sketch. The education sketch point out that higher education should emphasize practice and training in the period of teaching, so we establish strong relationship between enterprise and school, 
these will promote teaching, researching and producing at the same time. Therefore the higher education must face to the society, pay close attention to the economic construction trends, cultivate more talents with innovation spirits and working experience.

(3) Doing research for theory of the corporation education, improving the personal training system. In this process, we will further enrich, optimize curriculums and teaching plans. We send teachers, especially some young teacher to some research institutes or enterprises to do some research for a short period. We have the exchange students who do their research projects every year with other universities. All these will have some reference value for the theory.

(4) Doing some investigation for the corporation among education, research and practice. We often listen to the opinions comes form students, teachers and engineers in school or some factories and collect some data from employment market to figure out some evaluation. Thus to fund out a reality and effective personal training system for our education.

\section{The Present Corporation Education Conditions and Priority}

The corporations between universities and enterprises here in our country started later. But the trend of development and purpose may be the same compare with other countries. The functions of higher education is changing and developing day by days, so how to promote and combine teaching, research and production to meet with the needs of our society especially the local markets is now an important work and key research for us to carry out. For a university, we should break the "wall" of the campus of school, and build a close tie with enterprises. The education system of us would be more practical with application, adaptation and development. Now the main research of us is to figure out the best method for the corporation with enterprises, to pay more efforts for it and serve for it. Meanwhile we must have our own characteristics.

\section{The Target for the Research}

Establish the mood of corporation between university and enterprises. Based on the characteristic of automobile and electronic engineering, we carry out an education system which is oriented to the need of automobile industry, we mainly emphasize on practice ability for our students to be cultivated. Here we conclude the mood of "one main line, two tasks oriented, three principles and four stands out".

\subsection{One Main Line}

Pay close attention to the basic knowledge learning and engineering ability training;

\subsection{Two Tasks Oriented}

Face to the automobile-electronic market;

Face to the economic construction field and society and serve for them;

\subsection{Three Principles}

We must insist on "application, practice and market orientation", try our best to cultivate the talents with practice, innovation and creation ability;

Four stands out:

1. Engineering ability;

2. Combination of practice and theory;

3. Full of innovation ideas;

4. A well-trained personality. We now have established a friendly and regularly environment base for this kind of education system to cultivate our students.

\section{The Mood of Corporation between University and Enterprises}

According to different enterprise and specialized subject, we may first meet the need of the local industry, and make full use of them to meet our demands. We adopt the method which is the combination of practice in factory and teaching in the classroom, and try to cultivate the person who can meet the need of the enterprises who he or she will work there. Of course the graduates should not only meet the need of working places, but also is a person with innovation, creation and open ideas to meet the need of home and abroad. So we have several methods to carry out.

One step is to establish a base

The base is the place for the students to use the knowledge they learned in classroom for application, it has four kinds of functions:

1. Under the mutual benefits, we carried out the corporation between our university and enterprise. The base can provide finance supports and practice space, thus the corporation for both the university and factory will be feasible and also they will have the motivation to fulfill it. Both university and enterprise have their duties and obligations for do these things well.

2. Establish the frame of the teaching system. According to the demand of the high quality engineer, we divided three layers which are basic, profession and application. Among them, there are experiments, course design, graduate project, engineering project training and scientific research innovation. The experiments, course design, graduate project realized the basic engineering cultivation, while the engineering project training and scientific research innovation will form the strong characteristic of automobile industry for the education of our college in our university.

3. The method to carry out the teaching for application. The training will be divided different depths with different time period, and the progress will be step by step and finally reach a high level. 


\subsection{First Period}

We have exercitation, experiments besides the traditional teaching in classroom during the first and second semester years for freshman and sophomore. After these training, the students have both the scientific knowledge leant in classroom and also the knowledge in professional field, meanwhile acquire some basic ability for practice.

\subsection{Second Period}

We have course design, profession practice and so on. Mainly arrange in the late second year and the third years for sophomore and junior. The students will acquire some professional ability in some special fields through exercitation, experiments and also the study in classroom.

\subsection{Third Period}

We have engineering projects training, graduate design and some scientific innovation activities. And still more, send some students to some research institutes or enterprises (some are sent abroad) for the practice training and so on. Mainly arrange in the third and fourth year for junior and senior.

\subsection{Fourth Period}

We establish the support conditions such as the engineering training base for practice and experiments. The students will have the real environment for the training. And even we have the oriented training for enterprise. That is to cultivate the students directly for the need of some factory or institute. After the graduation, the student can serve for the factory or institute at once, so as to solve the problem of employment.

\subsection{One More Step Is to Have a Good Teaching Team}

In order to have the qualified students, we must also have qualified teachers. The teachers should have new ideas of education, a strong foundation of scientific knowledge and engineering background so that the education reform can be realized. Nowadays we arrange and send teachers to further their study to some famous universities home and abroad. We also invite experts who are with rich experience in engineering fields to our university as the adjunct professor to give some lectures for our teachers and students. We also encourage some young teachers to some enterprise to hang duty to take exercise. Making use of the summer vocation, the teachers together with students will go to some enterprises or institutes to practice. Through the corporation between our university and enterprise, the teachers can absorb much new technology and research achievements to improve the education course system, then to write more useful textbook. At the same time in return to improve the quality of engineering training.

\subsection{Still one More Step Is to Do More Research}

In the research, the university and enterprise have made the common efforts, such as to establish the automobile electronic control system which links the internet to control automobile vehicle, combine the computer knowledge with electronics and mechanism ones. Thus we establish the base for students and teachers to take part in the research, training, innovation and even some competitions which encourages the students to have motivations to improve themselves.

\section{Something Need to Be Improved}

First, the teaching scheme of us for cooperative education is usually not democratic and scientific, because it is designed by only several leaders based on their ideas and will. They did not listen to the opinions come from ordinary teachers and students. So some teaching scheme has some mistakes, even some reversed teaching steps would happen.

Even if we have the democratic policy, the limited thinking of mankind will still have something which is not perfect or is a mistake, still more, the scientific knowledge and production markets is even changing. So we must change something for our teaching scheme now and then, however, the present education system of ours usually prevents us from doing so. Because nowadays all the teaching activities must obey the teaching scheme, not the other way round. Even if the teaching scheme is wrong or need to be changed. However the teaching scheme tends to be changed nothing for a long time till some leader wake up by himself (notice: if you point out, that means no chance for the change will happen; if you do nothing for it, that means there may be some chance. Here, to let the leaders to be great is the priority.). The ordinary person who teaches and is taught would do everything by the teaching scheme and do and should do nothing for the teaching scheme. So we hope this situation can be changed in the future.

Second, the evaluation system is not fair enough. For example, if a teacher is good or not, or if an education method is good or not was usually judged by only one or two person who was assigned by some leaders. Maybe this person had some teaching experience, however his knowledge and style is limited. He may not give out a fair judgement for different subjects. Still more the judgement should be given by students who are the real target of our teaching. However they never have this kind of right. Of course, there are some other things which will affect the fair judgement if it was judged by the students. That is the examination. So we should separate the examination and teaching, that is the teacher will not give examination to his own students. Some other teachers will make a test paper for these students. However, all these improvements could not be carried out in a short time. Sometime these things have the relationship with our whole education system, so the resistance force of inertia for these improvements is very strong, maybe we have to wait for it.

Third, the education funds from government are not enough besides the tuition fee from students. Maybe the 
enterprise we are cooperating with each other can give some funds, however this is also not enough. So we must try some other method to get more money. And with the development of our country, we think the eduction funds will be increased in the near future. We can establish more bases with more modernized equipment for our students and teachers to do more researches and experiments with real environments. And more computers linked with the internet to have more computer simulations.

\section{Conclusion}

For the target of the revitalizing of our country, the corporation between universities and local enterprise is a new and good path for our education. Meanwhile we should also try to attract more enterprise home and abroad. So we must pay more attention for this platform, to develop, to realize it. In the end the personnel training, professional construction, teaching and research will deeply root in the soil of local economics. Doing all these, the education resource will be rich and the result will be the best. We think both university and enterprise will be Win-win. And the most important thing is that the students benefit from it a lot. They will have both the knowledge from the classroom and also the practice experiments from the cooperative education in the base, in some factories or institutes before their graduation.

The research is financed by (Shanghai board of Education with the project of "Study of Cooperative Education Patter for the teaching, research and production in automobile electronic engineering".

Shanghai board of High Education, 2011, No.52)

\section{References}

[1] Du Xiang Wan.(2007) How to cultivate new talents with engineering innovation. Report summaries in High level Forum.

[2] Yang Chun Ting.(2009) The way of the training of software engineering talents by drawing lessons from foreign countries. Computer Education.

[3] Zhou Yu.(2010) The exploration of corporation of teaching, research and production between local universities and enterprise. High Education Research in Science and Engineering.

[4] Song Pei Wei.(2011) The ideas and ways of cultivation for the innovation ability of Distinguished Engineer. Electrical Education of China, 25 28.

[5] Li Chin Feng.(2007)The position of high education cultivation for talents and the Study of Cooperative Education for Pattern Selection. High education Research. 